\title{
Light and electron microscopic observations of Leptotheca koreana n. sp. (Myxosporea) in the kidney of cultured rockfish Sebastes schlegeli
}

\author{
Jae Bum Cho, Ki Hong Kim* \\ Department of Aquatic Life Medicine, Pukyong National University, Pusan 608-737, South Korea
}

\begin{abstract}
The structure and sporogenesis of Leptotheca koreana n. sp. from cultured rockfish Sebastes schlegeli from South Korea were studied by light and transmission electron microscopy. Broadly oval spores and disporous pseudoplasmodia were observed in the lumen of renal tubules. Spores were $8.59 \pm 1.25 \mu \mathrm{m}$ in length, $13.42 \pm 1.0 \mu \mathrm{m}$ in width in sutural view and $8.13 \pm 0.52 \mu \mathrm{m}$ in thickness in the plane perpendicular to the suture. The width of each valve was always smaller than spore length. Two spherical polar capsules were equal in size (3.86 $\pm 0.45 \mu \mathrm{m}$ in diameter) containing a polar filament with 6 to 7 turns, opening at the anterior end of the spore. Two uninucleate sporoplasms filled the spore cavity. The asynchronous division of secondary and tertiary cells and asynchronous development in spore formation of the present Leptotheca koreana resembled the disporous sphaerosporids. Cytoplasmic projections of pseudoplamodia were considered to be rhizoids, as they seem to strengthen the attachment to the epithelial cells of the renal tubules. The capsulogenic cells in early sporoblast had large amounts of rough endoplasmic reticulum but had a few Golgi apparatus.
\end{abstract}

KEY WORDS: Leptotheca koreana n. sp. · Cultured marine fish · South Korea Resale or republication not permitted without written consent of the publisher

\section{INTRODUCTION}

Fish-parasitic myxosporeans comprise an extraordinarily large number of species. The host specificity of the myxosporean species differs; however, it is always restricted to a well-definable circle of related hosts (Molnár 1994). Many species of the genus Leptotheca have been described in various fish hosts, and to our knowledge 7 species of the genus Leptotheca are known from wild marine fish of the genus Sebastes.

Ultrastructural characteristics of various developmental stages of Leptotheca elongata in the gall bladder of the hake Merluccius merluccius were reported by Desportes \& Théodoridès (1982). Recently, Tun et al. (2000) described developmental stages of L. fugu in the intestine of cultured tiger puffer Takifugu

*Corresponding author. E-mail: khkim@pknu.ac.kr rubripes based on the observations of Diff-Quick stained specimens.

The rockfish Sebastes schlegeli is an important cultured marine fish in Korea, and no myxosporean parasites have been reported from this fish species. In the present study, we found a Leptotheca species in the renal tubules of cultured rockfish for the first time, and classified it as a new species, Leptotheca koreana. Light microscopy and TEM were used to describe the spores and sporogenesis.

\section{MATERIALS AND METHODS}

Juvenile rockfish Sebastes schlegeli (10 to $15 \mathrm{~cm}$ in body length) were taken from commerical netcages in South Korea. Squash preparations of fresh tissues from kidney were examined by light microscope. Spores were described and measured according to the guide- 
lines for species description of myxosporeans by Lom \& Arthur (1989), and by using a light microscope equipped with an ocular micrometer and an image analysis software (ImageTool v2.0, UTHSCSA, San Antonio, TX, USA). Mean and standard deviations of each spore characteristic were obtained from 175 fresh mature spores.

For histological study, the kidney tissues were fixed in Bouin's solution and embedded in paraplast. Sections $5 \mu \mathrm{m}$ thick were stained with hematoxylin and eosin. For TEM study, portions of the kidney tissue were fixed in $2 \%$ glutaraldehyde at $4{ }^{\circ} \mathrm{C}$ overnight and postfixed with $\mathrm{OsO}_{4}$ in the same buffer for $2 \mathrm{~h}$. The specimens were dehydrated, embedded in resin and ultrathin-sectioned, stained with uranyl acetate and lead citrate, and examined by JEM1200 transmission electron microscope (JEOL Ltd, Tokyo, Japan).

\section{RESULTS}

\section{Spore characteristics of Leptotheca koreana n. sp.}

Mature spores (Figs $1 \& 2$ ) were broadly oval (sutural view), measuring $8.59 \pm 1.25 \mu \mathrm{m}$ in length, $13.42 \pm$ $1.0 \mu \mathrm{m}$ in width in sutural view and $8.13 \pm 0.52 \mu \mathrm{m}$ in thickness in the plane perpendicular to the suture.

A

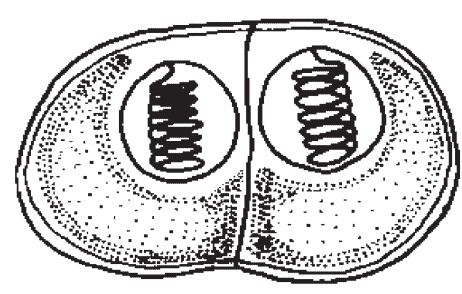

B

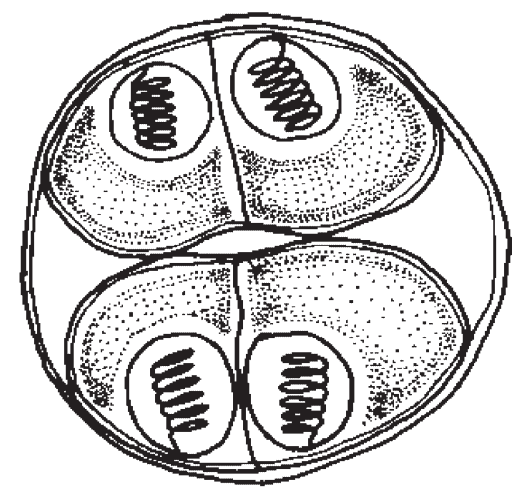

Fig. 1. Leptotheca koreana n. sp. infecting Sebastes schlegeli. Diagram of (A) mature spore and (B) disporous pseudoplasmodium. Scale bar $=10 \mu \mathrm{m}$
Valves were smooth and equal, and had an anterior notch just on the opening end of the polar capsule in each valve. The width of each valve was always smaller than spore length. Two spherical polar capsules were equal in size $(3.86 \pm 0.45 \mu \mathrm{m}$ in diameter $)$ containing a polar filament with 6 to 7 turns, opening at the anterior end of the spore. Two uninucleate sporoplasms filled the spore cavity.

Host: Rockfish Sebastes schlegeli

Locality: Hadong, Kyongsangnam-Do, South Korea Site of infection: Lumen of the renal tubules

Etymology: The specific name refers to the nation, Korea

Materials deposited: Laboratory of Fish and Shellfish Parasitology, Department of Aquatic Life Medicine, Pukyong National University, South Korea. Accession number PKNU-Pmy-9912

\section{Histology}

Host tissue response to infection with Leptotheca sp. was minimal, although large numbers of parasites were presented in the renal tubules of fish (Fig. 3).

\section{Transmission electron microscopy}

The earliest stage observed was an oval primary cell (pseudoplasmodium) containing 2 secondary cells (Fig. 4A). Each secondary cell produced a tertiary daughter cell (Fig. 4B,C), and subsequent divisions of the daughter cell gave rise to 6 tertiary cells (Fig. 4D). The primary cell in the lumen of the kidney tubules was in close contact with the micovilli of epithelial cells (Figs 4B \& 5A,B). At all junctions of tubular epithelial cells, the pseudoplasmodia sent out long finger-like pseudopodial projections between the microvilli.

Sporogenesis was asynchronous, and 2 spores were formed inside the same primary cell. In immature spores, 2 valvogenic cells, 2 capsulogenic cells and 2 uninucleated sporoplasms were observed (Fig. 5B). Valvogenic cells occupied an external position in relation to other sporogonic cells. They became elongated and flattened as the development of spores progressed and formed finely striated valves (Figs 5C,D \& 6B). Large capsulogenic cells occupied most of the spore volume (Fig. 5D). The cytoplasm of the capsulogenic cells contained high amounts of rough endoplasmic reticulum, several mitochondria and lipid droplets (Fig. 5B,D). Polar capsules were spherical and had a projection at the apical end (Fig. 5D). Three layers of different electron density were present in the capsule. Each mature polar capsule contained a 6 to 7 turns of the polar filament (Fig. 6A,B). 

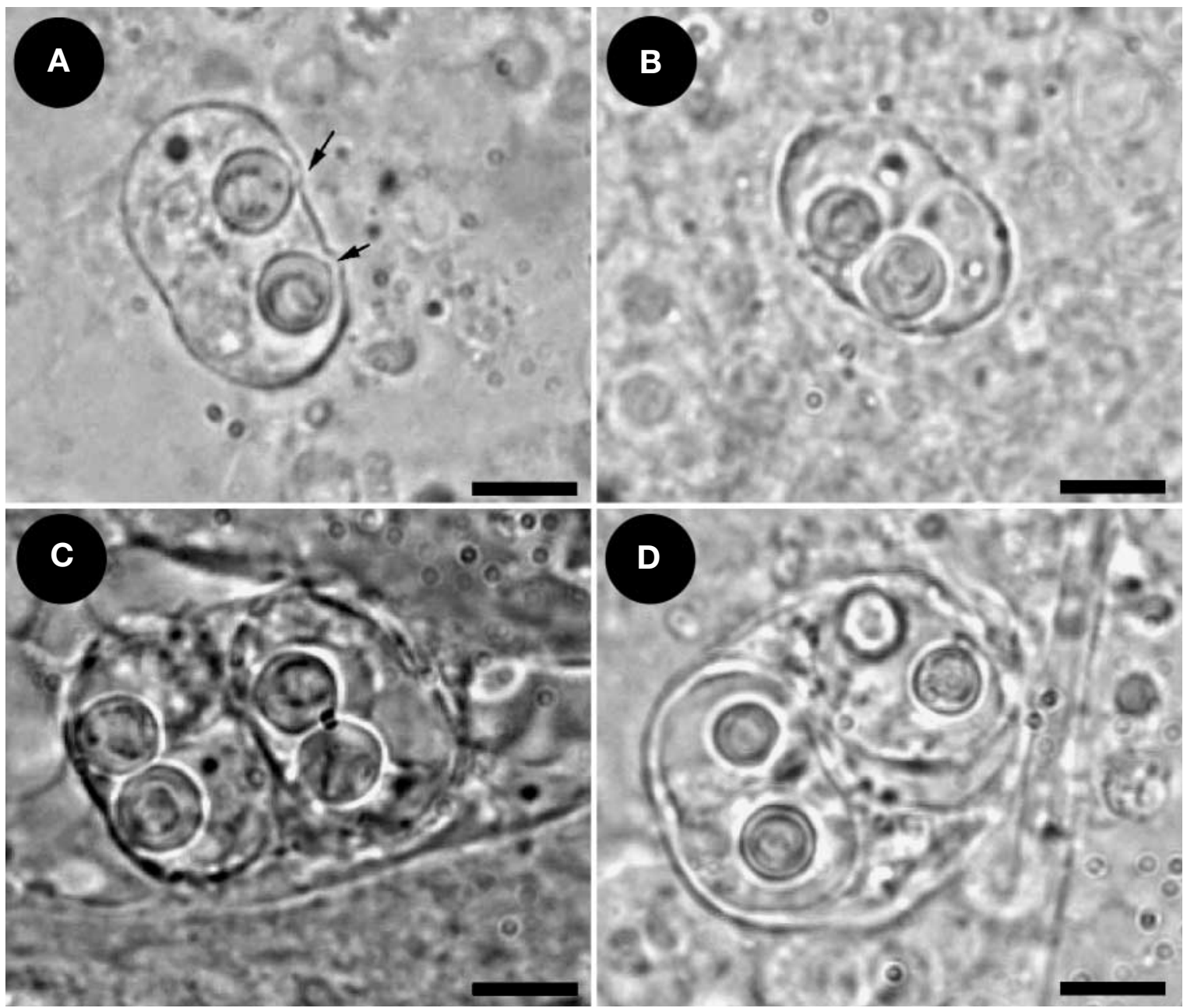

Fig. 2. Leptotheca koreana n. sp. infecting Sebastes schlegeli. (A,B) Mature spores from fresh preparations. Arrows indicate anterior notches. Scale bar $=5 \mu \mathrm{m}$. (C,D) Disporous pseudoplasmodia from fresh preparations. Scale bar $=5 \mu \mathrm{m}$

\section{DISCUSSION}

More than 40 species of myxosporeans in the genus Leptotheca have been described from fishes (Lom \& Dyková 1992), and among them, 7 species $-L$. macrospora, L. informis, L. longipes, L. sebasta, $L$. macroformis, $L$. kovaljovae and $L$. adeli-were found from the wild fish species of the genus Sebastes (Moser et al. 1976, Gaevskaya \& Kovaleva 1984, Love et al. 1984, Bakay \& Grudnev 1998, Kalavati \& MacKenzie 1999). Leptotheca koreana n. sp. in the present study was easily differentiated from the above Leptotheca species by combination of the following characters: spore size, spore shape, number of polar filament coils and sporoplasm condition. The length of the spore and the diameter of the polar capsule of $L$. koreana resembled that of $L$. informis in the gall bladder of several fish families including Anoplopomatidae, Gadidae,

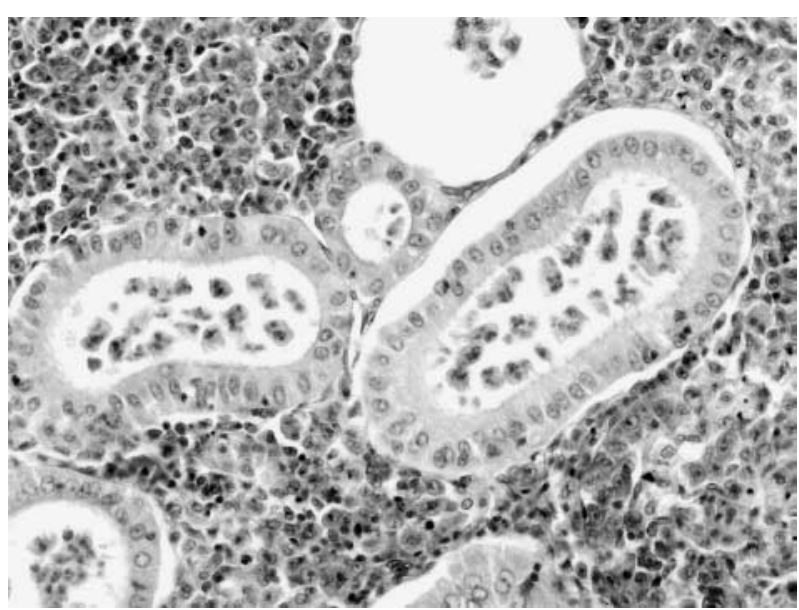

Fig. 3. Leptotheca koreana n. sp. infecting Sebastes schlegeli. Disporous plasmodia and mature spores have accumulated in the lumen of the kidney tubules 


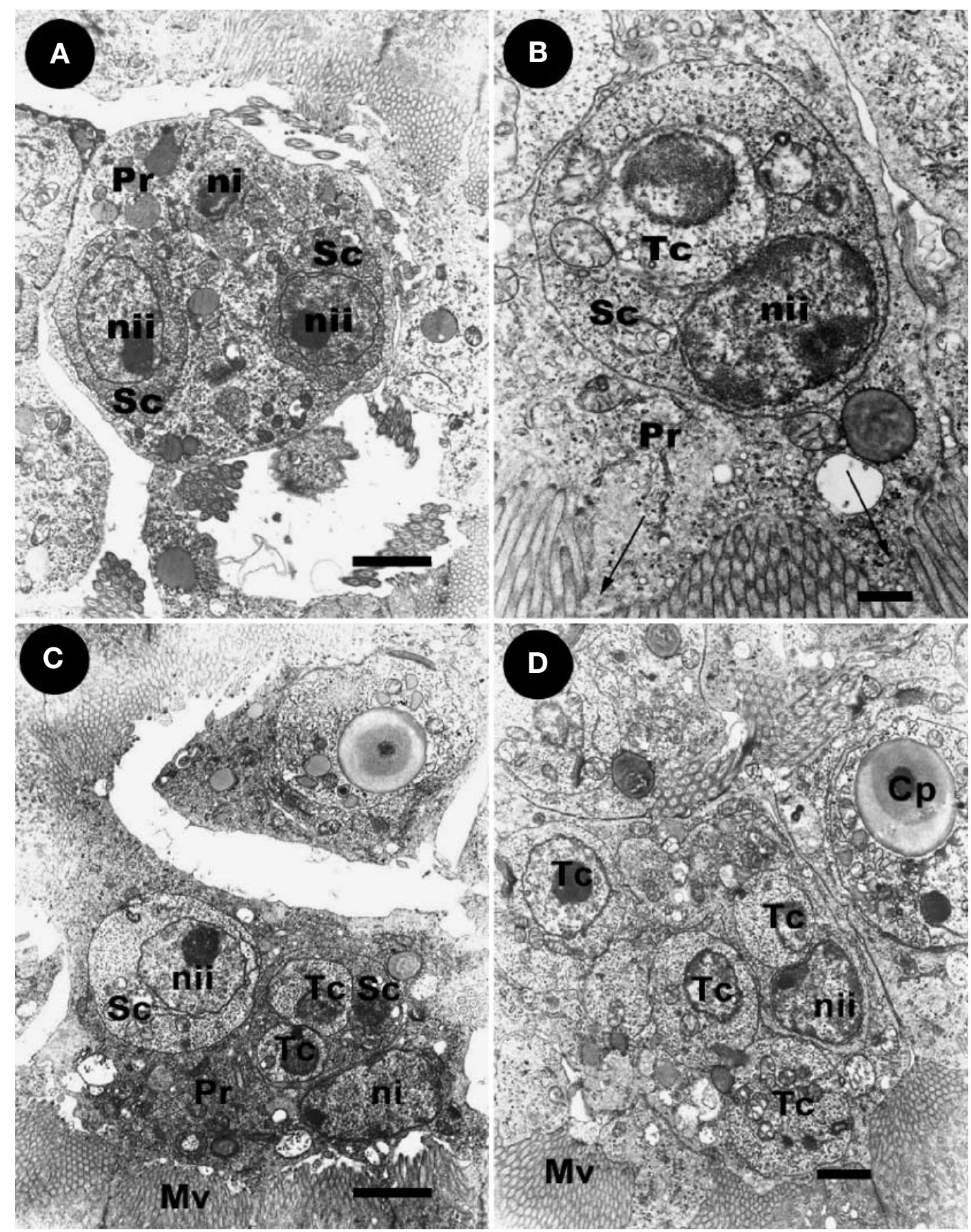

Fig. 4. Leptotheca koreana n. sp. infecting Sebastes schlegeli. (A) Primary cell (pseudoplasmodium, Pr) containing 2 secondary cells (Sc). ni: nucleus of primary cell; nii: nucleus of secondary cell. $\times 4000$, scale bar $=2 \mu \mathrm{m}$. (B) A secondary cell with a tertiary cell $(\mathrm{Tc})$. Arrows indicate finger-like projections of pseudoplasmodia. $\times 5000$, scale bar $=0.5 \mu \mathrm{m}$. (C) Pseudoplasmodium containing 2 secondary cells with asynchronous development. Mv: microvilli of kidney tubule. $\times 4000$, scale bar $=2 \mu \mathrm{m}$. (D) A secondary cell containing several tertiary cells. $\times 5000$, scale bar $=12 \mu \mathrm{m}$

Macrouridae and Scorpaenidae (Moser \& Noble 1976, Moser et al. 1976, Love et al. 1984, Kalavati \& MacKenzie 1999). However, L. koreana was clearly differentiated from $L$. informis by having 2 uninucleate sporoplasms, which was confirmed by TEM observation and distinctly smaller spore thickness.

According to Lom \& Dyková (1988), in myxosporean genera that have small mono- or disporic trophozoites, 


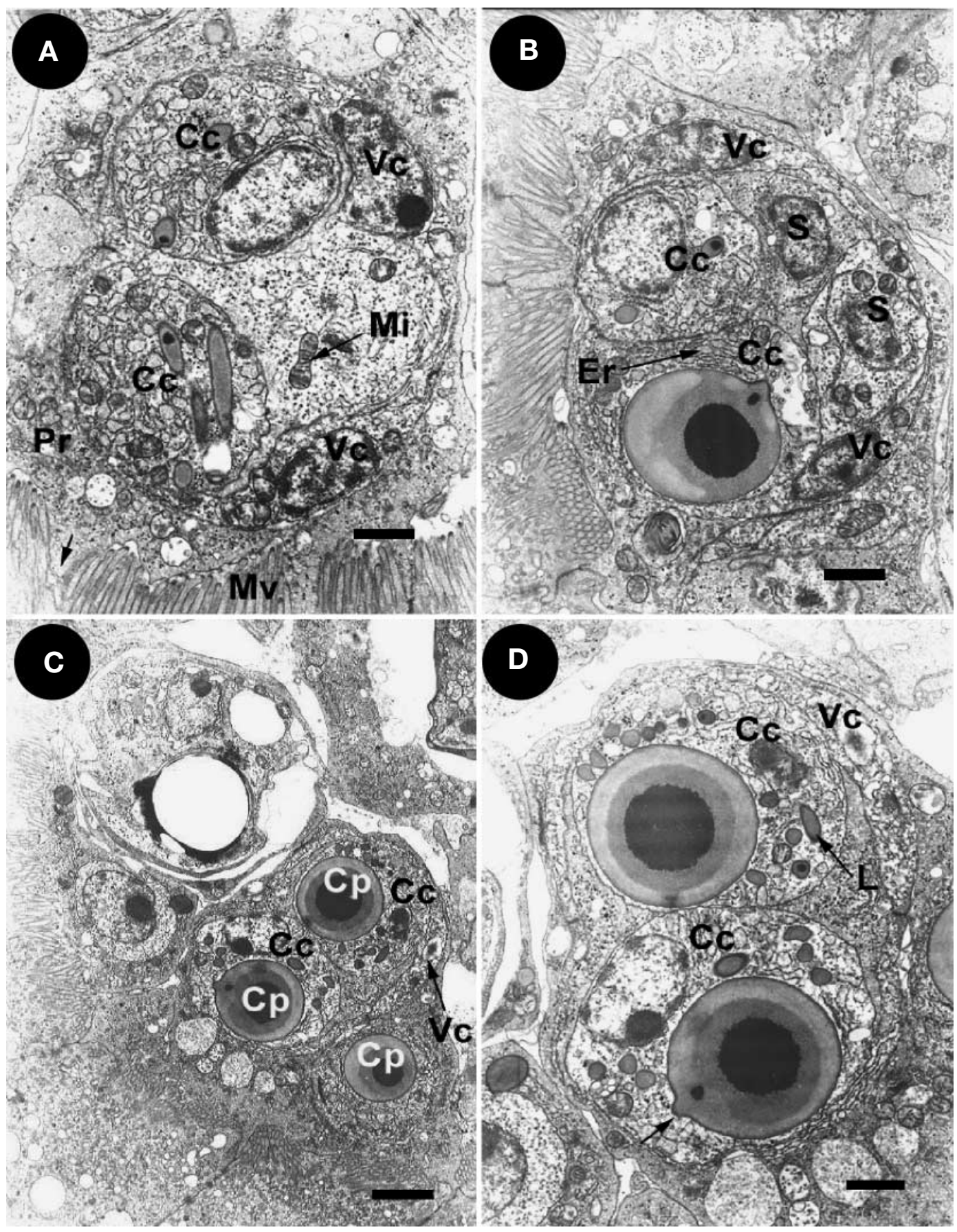

Fig. 5. Leptotheca koreana n. sp. infecting Sebastes schlegeli. (A) Two capsulogenic cells (Cc) and 2 valvogenic cells (Vc) in pseudoplasmodium (Pr). A short arrow indicates projection of pseudoplasmodium. Mi: mitochondria; Mv: microvilli of kidney tubule. $\times 6000$, scale bar $=1 \mu \mathrm{m}$. (B) An immature spore containing 2 capsulogenic cells, 2 valvogenic cells and 2 uninucleate sporoplasms (S). Er: rough endoplasmic reticulum. $\times 6000$, scale bar $=1 \mu \mathrm{m}$. (C) Disporous pseudoplasmodium. Each capsulogenic cell contains a capsular primordium (Cp). Valvogenic cells surround capsulogenic cells. $\times 3000$, scale bar $=2 \mu \mathrm{m}$. (D) Capsular primordia consist of 3 layers differing in electron density. An arrow indicates apical projection of polar capsule primordium. L: lipid droplet. $\times 6000$, scale bar $=1 \mu \mathrm{m}$

spores seem to be produced without pansporoblast formation. Rather, they are in the form of pseudoplasmodia with 1 vegetative nucleus, without the associa- tion of 2 generative cells. This has been well demonstrated in several species of Sphaerospora and Leptotheca (Desportes \& Théodoridès 1982, Desser et al. 


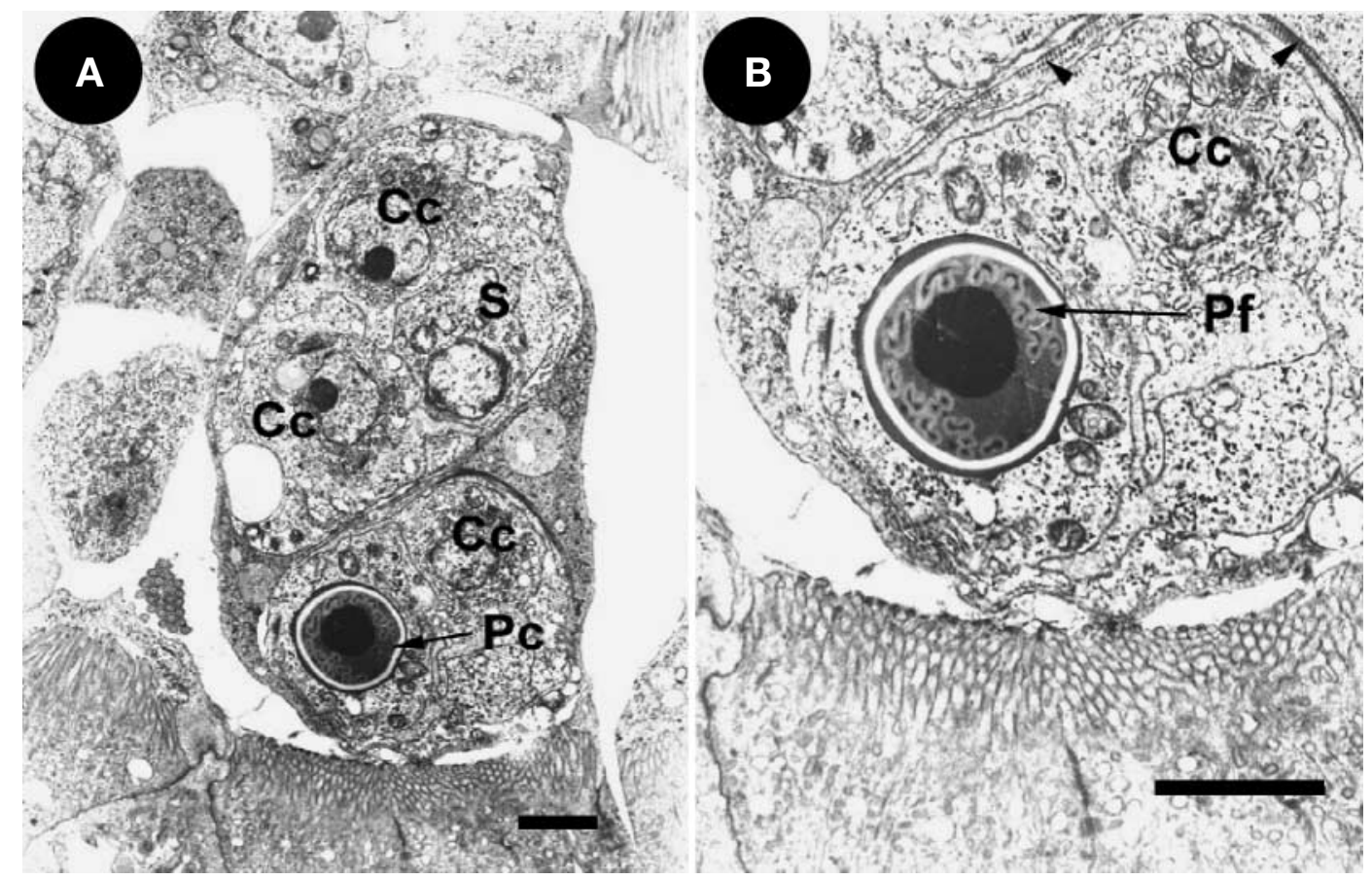

Fig. 6. Leptotheca koreana n. sp. infecting Sebastes schlegeli. (A) Disporous pseudoplasmodium showing asynchronous development. Pc: Polar capsule. $\times 3000$, bar $=2 \mu \mathrm{m}$. (B) Coiled polar filament (Pf) in a transverse section of a polar capsule. Arrowheads indicate fine striation in spore valve. $\times 6000$, scale bar $=2 \mu \mathrm{m}$

1983, Lom et al. 1982, 1985, Sitjà-Bobadilla \& AlvarezPellitero 1993a, Tun et al. 2000). Sporogenesis of Leptotheca koreana in this study followed this general trend pattern. The asynchronous division of secondary and tertiary cells and asynchronous development in spore formation of the present $L$. koreana resembled the disporous sphaerosporids (Desser et al. 1983, Lom et al. 1985, Dyková et al. 1990, Sitjà-Bobadilla \& Alvarez-Pellitero 1992, 1993a).

The cytoplasmic projections of pseudoplamodia formed in Leptotheca koreana were considered to be holdfast rhizoids, as they seem to strengthen the attachment to the epithelial cells of the renal tubules. These cytoplasmic outgrowths were also observed in Zschokkella mugilis in the lumen of the bile and gall bladder of mullets (Sitjà-Bobadilla \& Alvarez-Pellitero 1993b), Sinuolinea tetraodoni in kidney tubules of pufferfish (El-Matbouli \& Hoffmann 1994), Ceratomуха spp. from the gall bladder of Mediterranean sea bass (Alvarez-Pellitero \& Sitjà-Bobadilla 1993) and Myxidium giardi in the urinary bladder of eels (Paperna et al. 1987).

The capsulogenic cells in early sporoblast of Leptotheca koreana had large amounts of rough endoplasmic reticulum, but had a few Golgi apparatus. This is in accordance with similar observations in various other myxosporeans (Current \& Janovy 1978, Desportes \&
Théodoridès 1982, Davies \& Sienkowski 1988, Desser \& Paterson 1978, Desser et al. 1983, Lom \& Dyková 1988, Lom et al. 1985, Sitjà-Bobadilla \& Alvarez-Pellitero 1993b, El-Matbouli \& Hoffmann 1994).

Although infection with Leptotheca koreana had no apparent histological effects on the renal tubules, a finding consistent with other renal myxosporeans (Dyková \& Lom 1982, Fischer-Scherl et al. 1986, ElMatbouli \& Hoffmann 1992), occlusion of renal tubules by heavy infection with the parasites had detrimental effects on renal function.

Acknowledgements. This study was supported in part by the Academic Research Fund of Korea Science \& Engineering Foundation (981-0614-073-2), Republic of Korea.

\section{LITERATURE CITED}

Alvarez-Pellitero P, Sitjà-Bobadilla A (1993) Ceratomyxa spp. (Protozoa: Myxosporea) infections in wild and cultured sea bass, Dicentrarchus labrax (L.), from the Spanish Mediterranean area. J Fish Biol 42:889-901

Bakay YI, Grudnev MA (1998) New species of Mixosporidia (Cnidospora: Myxosporea) in redfishes of the North Atlantic. Parazitologiya 32:372-375 (in Russian)

Current WL, Janovy J (1978) Comparative study of ultrastructure of intralamellar types of Henneguya exilis Kudo from channel catfish. J Protozool 25:56-65 
Davies AJ, Sienkowski IK (1988) Further studies on Zschokkella russelli Tripathi (Myxozoa: Myxosporea) from Ciliata mustela L. (Teleostei: Gadidae), with emphasis on ultrastructural pathology and sporogenesis. J Fish Dis 11: 325-336

Desportes I, Théodoridès J (1982) Données ultrastructurales sur la sporogenèse de deux Myxosporidies rapportées aux genres Leptotheca et Ceratomyxa parasites de Merluccius merluccius (L.) (Téléostéen Merluciidae). Protistologica 18:533-557

Desser SS, Paterson B (1978) Ultrastructural and cytochemical observations on sporogenesis of Myxobolus sp. (Myxosporidia: Myxobolidae) from the common shiner Notropis cornutus. J Protozool 25:314-326

Desser SS, Molnár K, Horwath I (1983) An ultrastructural study of the myxosporeans, Sphaerospora angulata and Sphaerospora carassii, in the common carp, Cyprinus carpio L. J Protozool 30:415-422

Dyková I, Lom J (1982) Sphaerospora renicola n. sp.; a myxosporean from carp kidney, and its pathogenicity. Z Parasitenkd 68:259-268

Dyková I, Lom J, Körting W (1990) Light and electron microscopic observations on the swim bladder stages of Sphaerospora renicola, a parasite of carp (Cyprinus carpio). Parasitol Res 76:228-237

El-Matbouli M, Hoffmann RW (1992) Sphaerospora scardinii n. sp. (Myxosporea: Sphaerosporidae) observed in the kidney of rudd (Scardinus erythrophthalmus). Dis Aquat Org 14:23-29

El-Matbouli M, Hoffmann RW (1994) Sinuolinea tetraodoni n. sp., a myxosporean parasite of freshwater pufferfish Tetraodon palembangensis from Southeast Asia: light and electron microscope observations. Dis Aquat Org 19: 47-54

Fischer-Scherl T, El-Matbouli M, Hoffmann R (1986) A new Sphaerospora sp. in brown trout (Salmo trutta $m$, fario) in Germany. Bull Eur Assoc Fish Pathol 6:16-19

Gaevskaya AV, Kovaleva AA (1984) On the myxosporidian fauna of fish in the Celtic Sea. Vestn Zool 1984:3-7

Kalavati C, MacKenzie K (1999) The genera Ceratomyxa Thélohan, 1892, Leptotheca Thélohan, 1895 and Sphaeromyxa Thélohan, 1892 (Myxosporea: Bivalvulida) in gadid fish of the Northeast Atlantic. Syst Parasitol 43:209-216

Lom J, Arthur JR (1989) A guideline for the preparation of species descriptions in Myxosporea. J Fish Dis 12:151-156

Lom J, Dyková I (1988) Sporogenesis and spore structure in

Editorial responsibility: Wolfgang Körting,

Hannover, Germany
Kudoa lunata (Myxosporea, Multivalvulida). Parasitol Res 74:521-530

Lom J, Dyková I (1992) Protozoan parasites of fishes. Elsevier Science Publishers B.V., Amsterdam

Lom J, Dyková I, Lhotáková S (1982) Fine structure of Sphaerospora renicola Dyková and Lom, 1982 a myxosporean from carp kidney and comments of the origin of pansporoblasts. Protistologica 18:489-502

Lom J, Körting W, Dyková I (1985) Light and electron microscope redescription of Sphaerospora tincae Plehn, 1925 and S. galinae Evlanov, 1981 (Myxosporea) from the tench, Tinca tinca L. Protistologica 21:487-497

Love MS, Shriner K, Morris P (1984) Parasites of olive rockfish, Sebastes serranoides (Scorpaenidae) off central California. Fish Bull 82:530-536

Molnár K (1994) Comments on the host, organ and tissue specificity of fish myxosporeans and on the types of their intrapiscine development. Parasitol Hung 27:5-20

Moser M, Noble ER (1976) The genus Leptotheca (Protozoa: Myxosporida) in macrourid fishes and sablefish, Anoplopoma fimbria. J Protozool 23:490-492

Moser M, Love MS, Jensen LA (1976) Myxosporidia (Protozoa) in California rockfish, Sebastes spp. J Parasitol 62: 690-692

Paperna I, Hartley AH, Cross RH (1987) Ultrastructural studies on the plasmodium of Myxidium giardi (Myxosporea) and its attachment to the epithelium of the urinary bladder. Int J Parasitol 17:813-819

Sitjà-Bobadilla A, Alvarez-Pellitero P (1992) Light and electron microscopic description of Sphaerospora dicentrarchi n. sp. (Myxosporea: Sphaerosporidae) from wild and cultured sea bass, Dicentrarchus labrax L. J Protozool 39: 273-281

Sitjà-Bobadilla A, Alvarez-Pellitero P (1993a) Ultrastructural and cytochemical observations on the sporogenesis of Sphaerospora testicularis (Protozoa: Myxosporea) from Mediterranean sea bass, Dicentrarchus labrax (L.). Eur J Protistol 29:219-229

Sitjà-Bobadilla A, Alvarez-Pellitero P (1993b) Zschokkella mugilis n. sp. (Myxosporea: Bivalvulida) from mullets (Teleostei: Mugilidae) of Mediterranean waters: Light and electron microscopic description. J Eukaryot Microbiol 40:755-764

Tun T, Yokoyama H, Ogawa K, Wakabayashi H (2000) Myxosporeans and their hyperparasitic microsporeans in the intestine of emaciated tiger puffer. Fish Pathol 35:145-156

Submitted: January 30, 2001; Accepted: May 4, 2001

Proofs received from author(s): September 20, 2001 